\title{
Original paper \\ Ferraioloite from the Sítio do Castelo mine, Folgosinho (Guarda, Portugal), description and Raman spectroscopy
}

\author{
Jaromír TVRDÝ1*, Jiří SEJKORA², Pierre ROSSEEL³ , Zdeněk DOLNÍČEK² \\ ${ }^{1}$ Department of Geology, Faculty of Science, Masaryk University, Kotlářská 267/2, CZ-61137 Brno, Czech Republic; \\ jt.geologie@gmail.com \\ ${ }^{2}$ Department of Mineralogy and Petrology, National Museum, Cirkusová 1740, CZ-19300 Praha 9-Horní Počernice, Czech Republic \\ ${ }^{3}$ Nazaret dreef 103, B-2500 Lier, Belgium \\ * Corresponding author
}

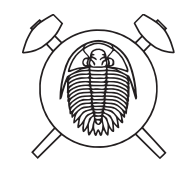

A zinc phosphate corresponding to ferraioloite with low $\mathrm{Mg}$ and high $\mathrm{Na}$ cation contents in interlayer space was identified in samples from the Sítio do Castelo mine, Folgosinho (Guarda, Portugal). It occurs as sky-blue, pearly lustrous, radial or irregular aggregates up to $1 \mathrm{~mm}$ in size composed of very thin elongated flaky crystals. The mineral is monoclinic, space group $I 2 / \mathrm{m}$, with unit-cell parameters refined from X-ray powder diffraction data: $a=25.417(7), b=6.342(4)$, $c=15.186(5) \AA, \beta=90.02(4)^{\circ}, V=2448.0(17) \AA^{3}$. The chemical composition generally agrees with published data for ferraioloite, but differs significantly in elements present at sites assumed to be in the interlayer of the crystal structure. The corresponding empirical formula based on $8(\mathrm{PO})_{4}$ and $4(\mathrm{OH})$ groups $p f u$ is $\left(\mathrm{Mg}_{0.16} \mathrm{Na}_{0.15} \mathrm{Ca}_{0.09} \mathrm{~K}_{0.01}\right)_{\Sigma 0.41} \mathrm{Mn}_{4.22}\left(\mathrm{Fe}^{2+}{ }_{1.64}\right.$ $\left.\mathrm{Fe}^{3+}{ }_{1.15} \mathrm{Al}_{1.47}\right)_{\Sigma 4.26} \mathrm{Zn}_{3.87}\left(\mathrm{PO}_{4}\right)_{8}(\mathrm{OH})_{4}\left(\mathrm{H}_{2} \mathrm{O}\right)_{20}$. The Raman spectra and tentative assignment of observed bands are given. The most prominent bands are attributed to stretching and bending vibrations of phosphate tetrahedra and complex metal-centered polyhedra. Bands of $\mathrm{O}-\mathrm{H}$ stretching vibrations are weak, and bending vibrations of water molecules were not observed. The origin of the mineral is related to in-situ supergene weathering of zwieselite-triplite and isokite-fluorapatite assemblages with admixtures of sphalerite.

Keywords: ferraioloite, powder X-ray diffraction, chemical composition, Raman spectroscopy, supergene weathering Received: 10 April 2021; accepted: 15 September 2021; handling editor: R. Skála

\section{Introduction}

Ferraioloite, ideally $\mathrm{MgMn}^{2+}{ }_{4}\left(\mathrm{Fe}^{2+}{ }_{0.5} \mathrm{Al}^{3+}{ }_{0.5}\right)_{4} \mathrm{Zn}_{4}\left(\mathrm{PO}_{4}\right)_{8}$ $(\mathrm{OH})_{4}\left(\mathrm{H}_{2} \mathrm{O}\right)_{20}$, was described as a new mineral by Mills et al. (2016) from the Foote Lithium Company mine, Kings Mountain district (North Carolina, USA), a pegmatite locality well known for a variety of rare phosphates and silicates. Structurally and chemically, ferraioloite is related to falsterite, $\mathrm{Ca}_{2} \mathrm{MgMn}_{2}{ }_{2}\left(\mathrm{Fe}^{2+}{ }_{0.5} \mathrm{Fe}^{3+}{ }_{0.5}\right)_{4} \mathrm{Zn}_{4}\left(\mathrm{PO}_{4}\right)_{8}$ $(\mathrm{OH})_{4}\left(\mathrm{H}_{2} \mathrm{O}\right)_{14}$ (Kampf et al. 2012). Both have a complex layer structure consisting of thick heteropolyhedral slabs bridged either by dimers of $\mathrm{MgO}_{6}$ octahedra (in falsterite) or by hydrogen-bonded isolated $\mathrm{Mg}\left(\mathrm{H}_{2} \mathrm{O}\right)_{6}$ octahedra (in ferraioloite). During the study of secondary phosphates from Sítio do Castelo mine, Folgosinho (Guarda, Portugal), a mineral phase corresponding to ferraioloite was confirmed by powder X-ray diffraction and chemical electron microprobe (EMP) analysis.

\section{Occurrence}

The Sítio do Castelo mine is located in the Serra da Estrela National Park in central Portugal, in the valley of the Freixo stream, about $500 \mathrm{~m}$ east of the center of the medieval Folgosinho village (40.511389, -7.508056). The first mining works date to 1917 when a wolframite(cassiterite?)-bearing quartz lens was exploited. After World War II, the mine was closed due to decreased metal prices. It was reopened by a small wall quarry in 1976 and exploited for quartz raw material used for metallic silicon production until 1986. In 1998, the mine was declared officially "extinct" (Alves et al. 2016).

The previously mined $\mathrm{W}-(\mathrm{Sn})$ ores probably occurred in isolated quartz veins at several small mines in the surrounding area. According to Teixeira et al. (1967), the thickness of these veins ranges from 0.15 to 0.80 $\mathrm{m}$. In the Sítio do Castelo mine, the ore mineralization was followed by a system of short (no more than $150 \mathrm{~m}$ ) galleries extending upslope more than 50 meters above the quarry level. The relationship between these veins and the main quartz body exposed in the mine is not entirely clear. The main quartz body is about $5 \mathrm{~m}$ thick and steeply penetrates migmatitized schists. It is considered to be either the core of a large pegmatite body (pers. comm. A. Lima 2021) or a high-temperature hydrothermal vein accompanied by greisenization with the local presence of andalusite, garnet and gahnite (Garate-Olabe et al. 2012).

Irregular phosphate accumulations and sulphide aggregates (pyrite $>>$ arsenopyrite $>>$ chalcopyrite $>>$ 
sphalerite) occur frequently in the main body. Primary phosphates are represented predominantly by zwieselitetriplite and less commonly by isokite with admixed fluorapatite. Intense weathering yielded varied secondary phosphate assemblages, which differ concerning their source mineral. Related to alteration of zwieselite-triplite, there is an assemblage, which includes phosphosiderite, strengite, rockbridgeite-frondelite, cacoxenite, bermanite, beraunite, strunzite, stewartite, laueite, leucophosphite, benyacarite, fluorapatite, wavellite and kidwellite. Related to the alteration of triplite-zwieselite in association with fluorapatite and isokite, there is an assemblage, which includes ludlamite, vivianite, strunzitezincostrunzite, $\mathrm{Zn}$-rich rockbridgeite-frondelite, Mn-rich phosphophyllite, hydroxylapatite, jahnsite-(CaMnFe), earlshannonite, lun'okite and plimerite (Alves et al. 2012; Kampf et al. 2017). Ferraioloite reported herein occurs in the latter assemblage.

\section{Sample description}

Ferraioloite occurs in fissures at the contact of brownish resinous massive zwieselite-triplite with fine-grained grey isokite with admixed fluorapatite and sphalerite. The walls of the fissures are rimmed by abundant muscovite blades up to $1 \mathrm{~mm}$ in size.

The mineral forms very thin, elongated, irregular flakes up to $0.25 \mathrm{~mm}$ in length arranged in fan-shaped to lamellar aggregates (Fig. 1). The flakes are pale blue and transparent, with pearly luster and pale blue streak. They are flexible and show irregular fracture and perfect cleavage on $\{010\}$. Because of its pale blue color, the ferraioloite described here visually resembles the related

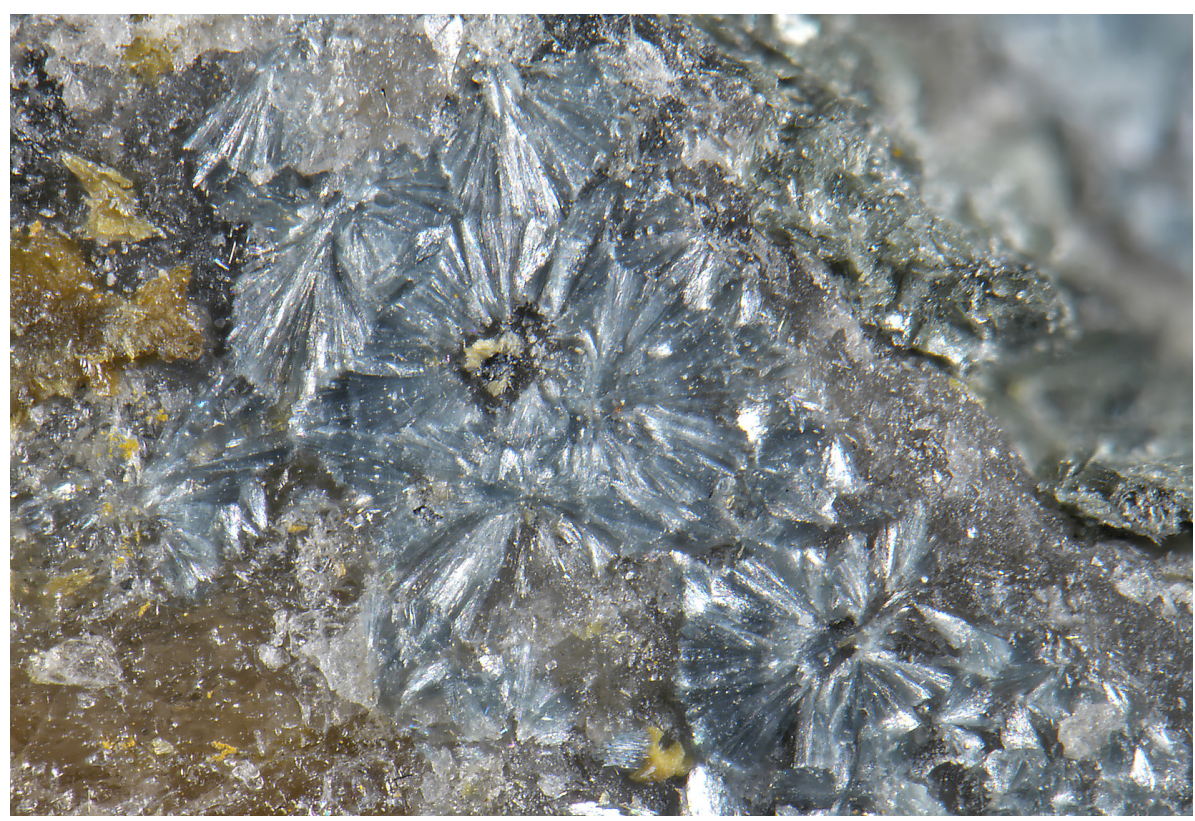

Zn-phosphate falsterite, rather than known samples of ferraioloite.

Minerals associated with ferraioloite include vivianite-metavivianite, earlshannonite-whitmoreite, jahnsitekeckite, strunzite-zincostrunzite, very rare lun'okite and several unspecified secondary phosphates. Ferraioloite was found by one of the authors (PR) in 2017 and 2018, and no samples have been found since.

The studied sample is deposited in the collections of the Department of Mineralogy and Petrology of the National Museum in Prague, Czech Republic, under the catalog number P1P 10/2021.

\section{Chemical composition}

The sample was analyzed with a Cameca SX-100 electron microprobe (National Museum, Prague) operated in the wavelength-dispersive mode with an accelerating voltage of $15 \mathrm{kV}$, a specimen current of $5 \mathrm{nA}$, and a beam diameter of 3-5 $\mu \mathrm{m}$. The following lines and standards were used: $K_{\alpha}$ : albite $(\mathrm{Na}), \mathrm{BN}(\mathrm{N})$, celestine $(\mathrm{S})$, chalcopyrite $(\mathrm{Cu}), \mathrm{Co}(\mathrm{Co}), \mathrm{Cr}_{2} \mathrm{O}_{3}(\mathrm{Cr})$, diopside $(\mathrm{Mg})$, fluorapatite $(\mathrm{Ca}, \mathrm{P})$, halite $(\mathrm{Cl})$, hematite $(\mathrm{Fe}), \mathrm{LiF}(\mathrm{F})$, $\mathrm{Ni}(\mathrm{Ni})$, rhodonite $(\mathrm{Mn})$, sanidine $(\mathrm{Al}, \mathrm{K}, \mathrm{Si}), \mathrm{TiO}_{2}(\mathrm{Ti})$, vanadinite $(\mathrm{V}), \mathrm{ZnO}(\mathrm{Zn}) ; L_{\alpha}$ : baryte $(\mathrm{Ba})$, clinoclase (As), scheelite (W), Sn (Sn), wulfenite (Mo), $\mathrm{YVO}_{4}(\mathrm{Y})$; $L_{\beta}$ : celestine ( $\left.\mathrm{Sr}\right) ; M_{\alpha}$ : bismuth $(\mathrm{Bi}), \mathrm{Th}(\mathrm{Th}), \mathrm{UO}_{2}(\mathrm{U})$ and wulfenite $(\mathrm{Pb})$. Peak counting times (CT) were $20 \mathrm{~s}$ for all elements except for N, for which it was $100 \mathrm{~s}$; CT for each background was one-half of the peak counting time. The raw intensities were converted to the concentrations automatically using the PAP (Pouchou and Pichoir 1985) matrix-correction procedure. The contents of As, $\mathrm{Ba}, \mathrm{Bi}, \mathrm{Cl}, \mathrm{Co}, \mathrm{Cr}, \mathrm{Cu}, \mathrm{F}, \mathrm{Mo}$, $\mathrm{N}, \mathrm{Pb}, \mathrm{S}, \mathrm{Si}, \mathrm{Sn}, \mathrm{Sr}, \mathrm{Ti}, \mathrm{Th}, \mathrm{U}$, $\mathrm{V}, \mathrm{W}$ and $\mathrm{Y}$ always were found to be below the detection limit (ca. 0.04-0.20 wt. \%). Water content could not be analyzed directly because of the minute amount of material available. The $\mathrm{H}_{2} \mathrm{O}$ content was confirmed by Raman spectroscopy and calculated based on the stoichiometry of the ideal formula. To maintain the charge balance and the number of $(\mathrm{OH})$ equal to 4 apfu, both valence states of iron have been considered. The

Fig. 1 Pale blue radial aggregates of leafy crystals of ferraioloite from the Sítio do Castelo mine. FOV $0.8 \mathrm{~mm}$. Photo J. Sejkora. 
Tab. 1 Chemical composition of ferraioloite from the Sítio do Castelo mine (wt. \%)

\begin{tabular}{lrcc}
\hline & Mean & Range & SD \\
\hline $\mathrm{Na}_{2} \mathrm{O}$ & 0.26 & $0.12-0.60$ & 0.16 \\
$\mathrm{~K}_{2} \mathrm{O}$ & 0.03 & $0.00-0.08$ & 0.03 \\
$\mathrm{CaO}$ & 0.28 & $0.20-0.48$ & 0.08 \\
$\mathrm{FeO}$ & 6.56 & $5.38-7.93$ & 0.95 \\
$\mathrm{MgO}$ & 0.35 & $0.27-0.45$ & 0.05 \\
$\mathrm{MnO}$ & 16.70 & $15.63-17.65$ & 0.63 \\
$\mathrm{ZnO}$ & 17.56 & $16.37-18.16$ & 0.54 \\
$\mathrm{Fe}_{2} \mathrm{O}_{3}$ & 5.13 & $3.04-6.87$ & 1.15 \\
$\mathrm{Al}_{2} \mathrm{O}_{3}$ & 4.19 & $3.48-5.10$ & 0.49 \\
$\mathrm{P}_{2} \mathrm{O}_{5}$ & 31.66 & $29.25-33.81$ & 1.17 \\
$\mathrm{H}_{2} \mathrm{O}^{*}$ & 22.10 & & \\
\hline Total & 104.82 & & \\
\hline
\end{tabular}

Mean and range of 9 analyses; $\mathrm{SD}$ - standard deviation; $\mathrm{H}_{2} \mathrm{O}^{*}-\mathrm{H}_{2} \mathrm{O}$ content calculated based on the theoretical assumed content of $20 \mathrm{H}_{2} \mathrm{O}$ $+4 \mathrm{OH} ; \mathrm{Fe}^{2+} / \mathrm{Fe}^{3+}$ ratio was inferred from the charge-balance.

presence of iron(III) is indirectly indicated by the blue color of the mineral, which was noted as indicative for $\mathrm{Fe}^{2+}-\mathrm{Fe}^{3+}$ charge transfer both in falsterite and ferraioloite (Kampf et al. 2012; Mills et al. 2016).

The analytical data are given in Tab. 1. The chemical composition and stoichiometry of the studied sample generally agree with the ideal formula of ferraioloite $\mathrm{Mg}$ $\mathrm{Mn}_{4}^{2+}\left(\mathrm{Fe}^{2+}{ }_{0.5} \mathrm{Al}^{3+}{ }_{0.5}\right){ }_{4} \mathrm{Zn}_{4}\left(\mathrm{PO}_{4}\right)_{8}(\mathrm{OH})_{4}\left(\mathrm{H}_{2} \mathrm{O}\right)_{20}$. The main difference is in its content of $\mathrm{Mg}$, the main cation in the interlayer, which is reported as $0.50 \mathrm{apfu}$ in the holotype and found to be only 0.16 apfu in the studied sample. The empirical formula of ferraioloite from the Sítio do Castelo mine (mean of 9 analyses) on the basis of $\mathrm{P}=$ 8 apfu and $(\mathrm{OH})=4$ is $\left(\mathrm{Mg}_{0.16} \mathrm{Na}_{0.15} \mathrm{Ca}_{0.09} \mathrm{~K}_{0.01}\right)_{\Sigma 0.41} \mathrm{Mn}_{4.22}$ $\left(\mathrm{Fe}^{2+}{ }_{1.64} \mathrm{Fe}^{3+}{ }_{1.15} \mathrm{Al}_{1.47}\right)_{\Sigma 4.26} \mathrm{Zn}_{3.87}\left(\mathrm{PO}_{4}\right)_{8}(\mathrm{OH})_{4}\left(\mathrm{H}_{2} \mathrm{O}\right)_{20}$.

Considering substitutions reported for structurally related layered Zn-phosphates (i.e., Kampf et al. 2012; Grey et al. 2018), a general chemical formula $\mathrm{Mg}(M 1)_{4}(M 2)_{4} \mathrm{Zn}_{4}\left(\mathrm{PO}_{4}\right)_{8}(\mathrm{OH})_{4}\left(\mathrm{H}_{2} \mathrm{O}\right)_{\times}$can be derived for both ferraioloite and falsterite, where $M 1$ and $M 2$ always represent two structural sites. In ferraioloite, $M 1=\mathrm{Mn}^{2+}, M 2=\mathrm{Fe}^{2+}{ }_{0.5} \mathrm{Al}_{0.5}, \mathrm{x}=20$, and in falsterite, $M 1=\mathrm{Ca}_{0.5} \mathrm{Mn}^{2+}{ }_{0.5}, M 2=$ $\mathrm{Fe}^{2+}{ }_{0.5} \mathrm{Fe}^{3+}{ }_{0.5}, \mathrm{x}=14$. In these ideal formulas, $\mathrm{Mg}$ atoms occupy the interlayer and the remaining metals belong to the heteropolyhedral layer of atoms.

In the studied ferraioloite, 0.16 apfu $\mathrm{Mg}$ was found only. Other interlayer constituents must compensate for this deficiency, or the structure would undoubtedly contract in the c direction, which was not observed. The primary candidates interlayer space of ferraioloite to be accommodated in the interlayer space are $\mathrm{Na}, \mathrm{Ca}$ and $\mathrm{K}$; the resulting interlayer cation content is most likely $\left(\mathrm{Mg}_{0.16} \mathrm{Na}_{0.15} \mathrm{Ca}_{0.09} \mathrm{~K}_{0.01}\right)_{\Sigma 0.41}$. While Mg remains the dominant cation, it is almost equaled by $\mathrm{Na}$ and significantly exceeded by the total large-cation content. Almost identical content of large cations $(0.21$ apfu $\mathrm{Ca})$ is reported by Mills et al. (2016) in the original sample of ferraioloite, but without specification of its position in the crystal structure, its structural role, and without comments to an excess of the sum of metal atoms considered to be in heteropolyhedral sites. In falsterite (Kampf et al. 2012), the role of $\mathrm{Ca}$ in the structure is different (Tab. 2).

The structural analysis could help solve this problem, but unfortunately, no reliable single-crystal X-ray diffraction data are available because the mineral occurs as parallel intergrowths of very thin flakes.

\section{X-ray diffraction}

Powder X-ray diffraction data were collected on a Bruker D8 Advance diffractometer (National Museum, Prague) with a solid-state $1 \mathrm{D}$ LynxEye detector (width $2.05^{\circ}$ ) using $\mathrm{Cu} K_{\alpha}$ radiation and operating at $40 \mathrm{kV}$ and $40 \mathrm{~mA}$. The powder pattern was collected using Bragg-Brentano geometry in the range $3-70^{\circ} 2 \theta$, in $0.01^{\circ}$ steps with a counting time of $30 \mathrm{~s}$ per step. Positions and intensities of reflections were found and refined using the PearsonVII profile-shape function with the ZDS program package (Ondruš 1993) and the unit-cell parameters were refined by the least-squares algorithm implemented by Burnham (1962). The experimental powder pattern was indexed in line with the calculated values of intensities obtained by the Lazy Pulverix program (Yvon et al. 1977) from the crystal structure of ferraioloite (Mills et al. 2016).

The experimental powder data given in Tab. 3 agree well with the data published for this mineral from the original locality (Mills et al. 2016) and with the X-ray pattern calculated from the structure of ferraioloite; experimental intensities are partly affected by the preferred orientation

Tab. 2 Tentative site occupations in ferraioloite and falsterite, assuming presence of large cations in the

\begin{tabular}{|c|c|c|c|c|c|c|c|}
\hline \multicolumn{5}{|c|}{ Ferraioloite } & \multicolumn{3}{|c|}{ Falsterite } \\
\hline Ideally & \multicolumn{2}{|c|}{$\begin{array}{l}\text { Sample from Sítio do Castelo } \\
\text { mine (current study) }\end{array}$} & \multicolumn{2}{|c|}{$\begin{array}{l}\text { Foote mine, USA } \\
\text { (Mills et al. 2016) }\end{array}$} & Ideally & \multicolumn{2}{|l|}{$\begin{array}{l}\text { Palermo \#1, USA } \\
\text { (Kampf et al. 2012) }\end{array}$} \\
\hline \multicolumn{8}{|c|}{ Interlayer cations $(a p f u)$} \\
\hline $\mathrm{Mg}^{2+}$ & $\mathrm{Mg}^{2+}{ }_{0.16}$ & 0.16 & $\mathrm{Mg}^{2+}{ }_{0.50}$ & 0.50 & $\mathrm{Mg}^{2+}$ & $\mathrm{Mg}^{2+}{ }_{0.94} \mathrm{Zn}_{0.06}^{2+}$ & 1.00 \\
\hline \multirow[t]{2}{*}{ - } & $\mathrm{Na}_{0.15}^{+} \mathrm{Ca}^{2+}{ }_{0.09} \mathrm{~K}_{0.01}^{+}$ & 0.25 & $\mathrm{Ca}^{2+}{ }_{0.21}$ & 0.21 & - & - & - \\
\hline & $\Sigma$ & 0.41 & $\Sigma$ & 0.71 & & $\Sigma$ & 1.00 \\
\hline \multicolumn{8}{|c|}{ Heteropolyhedral layer atoms (apfu) } \\
\hline $\mathrm{Mn}^{2+}{ }_{4}$ & $\mathrm{Mn}_{4.22}^{2+}$ & 4.22 & $\mathrm{Mn}_{4.16}^{2+}$ & 4.16 & $\mathrm{Ca}^{2+}{ }_{2} \mathrm{Mn}^{2+}{ }_{2}$ & $\mathrm{Ca}^{2+}{ }_{2.02} \mathrm{Mn}^{2+}{ }_{2.04}$ & 4.06 \\
\hline $\mathrm{Fe}^{2+}{ }_{2} \mathrm{Al}^{3+}$ & $\mathrm{Fe}^{2+}{ }_{1.64} \mathrm{Fe}^{3+}{ }_{1.15} \mathrm{Al}_{1.47}$ & 4.26 & $\mathrm{Fe}^{2+}{ }_{2.05} \mathrm{Al}_{2.01}$ & 4.06 & $\mathrm{Fe}^{2+}{ }_{2} \mathrm{Fe}_{2}^{3+}$ & $\mathrm{Fe}^{2+}{ }_{1.99} \mathrm{Fe}^{3+}{ }_{1.99} \mathrm{Al}^{3+}{ }_{0.01}$ & 3.99 \\
\hline \multirow[t]{2}{*}{$\mathrm{Zn}^{2+}{ }_{4}$} & $\mathrm{Zn}^{2+}{ }_{3.87}$ & 3.87 & $\mathrm{Zn}_{4.27}$ & 4.27 & $\mathrm{Zn}^{2+}{ }_{4}$ & $\mathrm{Zn}^{2+}{ }_{4.00}$ & 4.00 \\
\hline & $\Sigma$ & 12.35 & $\Sigma$ & 12.49 & & $\Sigma$ & 12.05 \\
\hline
\end{tabular}


Tab. 3 X-ray powder diffraction data for ferraioloite from the Sítio do Castelo Mine

\begin{tabular}{|c|c|c|c|c|c|c|c|}
\hline \multirow[b]{2}{*}{$h$} & \multirow[b]{2}{*}{$k$} & \multirow[b]{2}{*}{$l$} & \multirow[b]{2}{*}{$d_{\text {calc. }}$} & \multicolumn{2}{|c|}{ Sítio do Castelo mine (this paper) } & \multicolumn{2}{|c|}{ Foote mine, USA (Mills et al. 2016) } \\
\hline & & & & $d_{o b s .}$ & $I_{o b s .}$ & $d_{o b s}$ & $I_{o b s .}$ \\
\hline 2 & 0 & 0 & 12.709 & 12.707 & 100.0 & 12.7 & 100 \\
\hline 0 & 0 & 2 & 7.593 & 7.596 & 0.6 & 7.58 & 1 \\
\hline 4 & 0 & 0 & 6.354 & 6.356 & 1.0 & & \\
\hline 1 & 0 & 3 & 4.964 & ) & & & \\
\hline 1 & 0 & -3 & 4.965 & 4.962 & 0.3 & 4.95 & 1 \\
\hline 5 & 0 & -1 & 4.821 & 4.832 & 0.1 & & \\
\hline 1 & 1 & -2 & 4.781 & 4782 & & & \\
\hline 1 & 1 & 2 & 4.781 & 4.783 & 0.3 & 4.78 & 4 \\
\hline 3 & 0 & -3 & 4.346 & 4324 & & & \\
\hline 3 & 0 & 3 & 4.345 & 4.334 & 0.1 & 4.33 & 1 \\
\hline 6 & 0 & 0 & 4.236 & 4.237 & 3.0 & 4.22 & 4 \\
\hline 6 & 0 & -2 & 3.700 & 2680 & & & \\
\hline 6 & 0 & 2 & 3.699 & 3.699 & 0.8 & 3.699 & 3 \\
\hline 5 & 0 & 3 & 3.586 & 3.592 & 0.2 & 3.580 & 4 \\
\hline 5 & 1 & -2 & 3.516 & 3510 & 05 & 300 & 5 \\
\hline 5 & 1 & 2 & 3.515 & \} & 0.5 & 3.499 & 5 \\
\hline 1 & 1 & -4 & 3.231 & 3.230 & 0.2 & 3.245 & 7 \\
\hline 1 & 0 & -5 & 3.016 & 3018 & 0 & 3000 & 1 \\
\hline 1 & 0 & 5 & 3.016 & \} & 0.9 & 3.000 & 1 \\
\hline 8 & 0 & -2 & 2.931 & 2.931 & 0.5 & 2.924 & 8 \\
\hline 3 & 0 & -5 & 2.859 & 867 & 3 & 2860 & 5 \\
\hline 3 & 0 & 5 & 2.859 & \} & 0.3 & 2.869 & 5 \\
\hline 7 & 0 & -4 & 2.624 & 2.624 & 1.3 & 2.616 & 4 \\
\hline 10 & 1 & 1 & 2.3313 & 2.3324 & 0.1 & 2.352 & 2 \\
\hline 12 & 0 & 0 & 2.1181 & 2.1209 & 0.1 & 2.113 & 2 \\
\hline 6 & 2 & 4 & 2.1101 & 2.1063 & 0.1 & & \\
\hline 9 & 2 & -1 & 2.0890 & 2.0879 & 0.1 & 2.083 & 2 \\
\hline 0 & 0 & 8 & 1.8982 & 1.8971 & 0.2 & 1.8942 & 2 \\
\hline 2 & 3 & 5 & 1.7191 & 1.7203 & 0.3 & & \\
\hline 15 & 0 & -1 & 1.6841 & ) & - 1 & & \\
\hline 15 & 0 & 1 & 1.6840 & 1.0832 & 0.1 & & \\
\hline
\end{tabular}

Raman Spectrometer (Thermo Scientific) mounted on a confocal Olympus microscope. The Raman signal was excited by an unpolarised $633 \mathrm{~nm} \mathrm{He}-\mathrm{Ne}$ gas laser and detected by a CCD detector (size $1650 \times 200$ pixels, Peltier-cooled to $-60^{\circ} \mathrm{C}$, quantum efficiency of $50 \%$ and dynamic range $360-1100 \mathrm{~nm}$ ). The experimental parameters were: $100 \times$ objective, $10 \mathrm{~s}$ exposure time, accumulation of 100 exposures, $25 \mu \mathrm{m}$ pinhole spectrograph aperture, $2 \mathrm{~mW}$ laser power level, grating 400 per $\mathrm{mm}$ (estimated resolution $\left.6.4-13.3 \mathrm{~cm}^{-1}\right)$. The spectra were repeatedly acquired from different grains to obtain a representative spectrum with the best signal-to-noise ratio. The possible thermal damage of the measured point was assessed by visual inspection of the exposed surface after measurement, observing possible decay of spectral features at the start of excitation and checking for thermal downshift of Raman lines. The instrument was set up by a software-controlled calibration procedure using multiple neon emission lines (wavelength calibration), multiple polystyrene Raman bands (laser-frequency calibration) and standardized white-light sources (intensity calibration).

Spectral manipulations were performed using the Omnic 9 software (Thermo Scientific). Gaussian/Lorentzian (pseudo-Voigt) profile functions of the band-shape were used to obtain decomposed band components of the spectra. The decomposition was based on minimizing the difference in the observed and calculated profiles until the squared correlation coefficient $\left(r^{2}\right)$ was greater than 0.995 .

To our knowledge, vibration spectra for ferraioloite have not yet been published. According to Mills et al. (2016), the mineral has a heteropolyhedral layer structure, with layers parallel to (100). The slabs consist of $\left[\mathrm{Mn}^{2+}{ }_{4}\left(\mathrm{Fe}^{2+}{ }_{0.5} \mathrm{Al}^{3+}{ }_{0.5}\right)_{4} \mathrm{Zn}_{4}\left(\mathrm{PO}_{4}\right)_{8}(\mathrm{OH})_{4}\left(\mathrm{H}_{2} \mathrm{O}\right)_{8}\right]$ units built by (i) chains of pentamers formed by edge-shared dimers of $\left[(\mathrm{Fe}, \mathrm{Al}) \mathrm{O}_{6}\right]$ and $\left[(\mathrm{Fe}, \mathrm{Al}) \mathrm{O}_{4}(\mathrm{OH})_{2}\right]$ octahedra with wedged $\left[\mathrm{MnO}_{4}\left(\mathrm{H}_{2} \mathrm{O}\right)_{2}\right]$ octahedra, and (ii) parallel chains of edgeshared $\left[\mathrm{ZnO}_{4}\right]$ tetrahedra, both linked by $\left[\mathrm{PO}_{4}\right]$ tetrahedra 
(a)



(b)

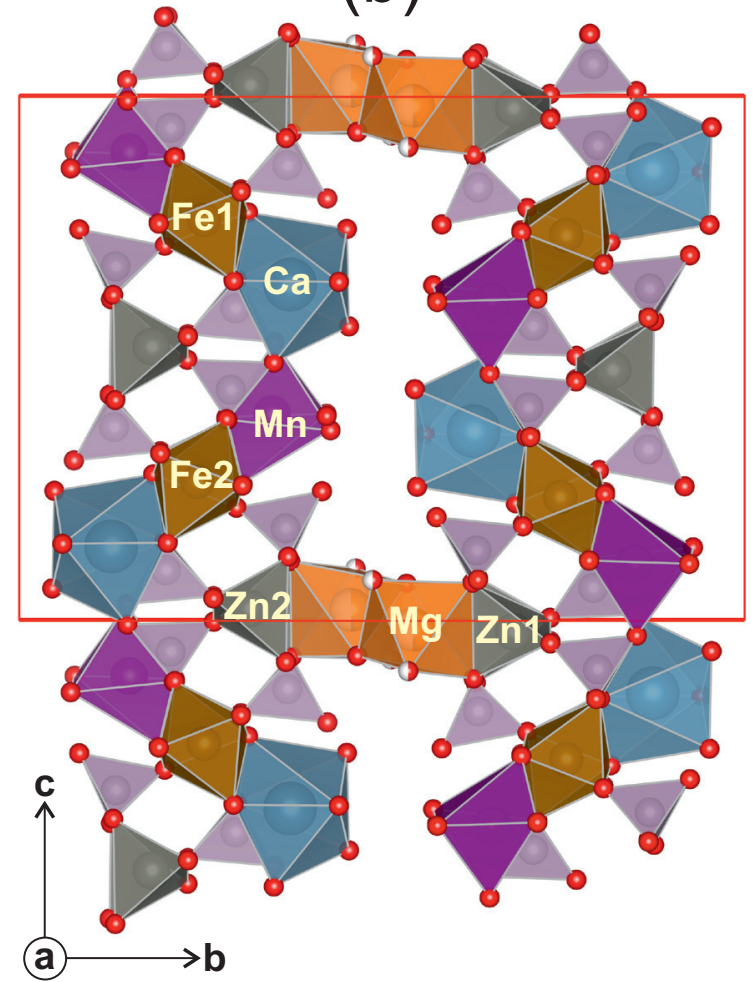

Fig. 2 Projections of the layered crystal structure of ferraioloite (a) and falsterite (b) according to data of Mills et al. (2016) and Kampf et al. (2012). Atoms of adjacent layers are omitted. Dashed lines correspond to hydrogen bonds between interlayer water molecules and layer oxygen atoms in ferraioloite.

(Fig. 2). The anions forming shared edges between the $\mathrm{Mn}$-centred and Fe-centred octahedra are hydroxyl ions, and the unshared vertices of the Mn-centred octahedra are water molecules. The hydroxyl ions are partly deprotonated, maintaining a charge balance of the $\mathrm{Fe}^{2+}-\mathrm{Al}^{3+}$ heterovalent exchange. Isolated $\left[\mathrm{Mg}\left(\mathrm{H}_{2} \mathrm{O}\right)_{6}\right]$ octahedra, packing water molecules and most probably also $\mathrm{Ca}$ and/ or $\mathrm{Na}$ are located in the interlayer. The cohesion is maintained by hydrogen bonding between the water molecules and oxygen acceptors.

According to Nakamoto (2009), octahedral units $\mathrm{XY}_{6}$ exhibit six normal modes of vibration. Three of them are Raman active, $v_{1}\left(A_{1 \mathrm{~g}}\right)$ and $v_{2}\left(E_{\mathrm{g}}\right)$ stretching vibrations and $v_{5}\left(F_{2 \mathrm{~g}}\right)$ bending vibration. Tetrahedral $\mathrm{XY}_{4}$ units with $T_{\mathrm{d}}$ symmetry have four normal modes of vibration, all Raman-active: $v_{1}\left(A_{1}\right)$ symmetric stretching vibration, $v_{2}(\delta)(E)$ doubly degenerate bending vibration, $v_{3}\left(F_{2}\right)$ triply degenerate antisymmetric stretching vibration, and $v_{4}(\delta)\left(F_{2}\right)$ triply degenerate bending vibration. In the crystalline state, deformation of polyhedra and lowering of symmetry leads to splitting of degenerate vibrations. Due to longer bond distances (from $1.942 \AA$ for $\mathrm{Zn}-\mathrm{O}$ up to $2.273 \AA$ for $\mathrm{Mn}-\mathrm{O}$; Mills et al. 2016), stretching and bending $M-\mathrm{O}$ vibrations are manifested in the region of low wavelengths, where they overlap with $\mathrm{PO}_{4}$ vibrations.
The experimental Raman spectrum of the studied sample from the Sítio do Castelo mine (Fig. 3) is in general similar to that of other hydrated hydroxyphosphates. Tentative band assignments are given in Tab. 5 .

The spectrum over the range $3800-2800 \mathrm{~cm}^{-1}$ is shown in Fig. 4a. As indicated by Chukanov and Vigasina (2020), Raman spectroscopy has a low sensitivity in the determination of water in minerals due to a weak response to excitation radiation. Bands of $\mathrm{O}-\mathrm{H}$ stretching vibrations are usually observed in the range from 3800 to $3000 \mathrm{~cm}^{-1}$, but bands of acidic $\mathrm{OH}$ groups and very strong hydrogen bonds may have Raman shifts below $3000 \mathrm{~cm}^{-1}$. In the studied sample, the two bands at 3594 and $3538 \mathrm{~cm}^{-1}$ are assigned to the stretching vibrations of the hydroxyl units. The broad feature of component bands at 2933 and $3170 \mathrm{~cm}^{-1}$ reflects vibrations of hydrogenbonded water molecules in the interlayer space.

Bands of $\mathrm{H}-\mathrm{O}-\mathrm{H} v_{2}(\delta)$ bending vibrations of water molecules, occasionally observed in related phosphate minerals in the range $1700-1600 \mathrm{~cm}^{-1}$, were not detected. A similar lack of these manifestations in the Raman spectrum of jasonsmithite is explained as being related to the existence of many different $\mathrm{H}_{2} \mathrm{O}$ sites resulting in many overlapping, broad low-intensity peaks not exceeding the background (Kampf et al. 2021). 


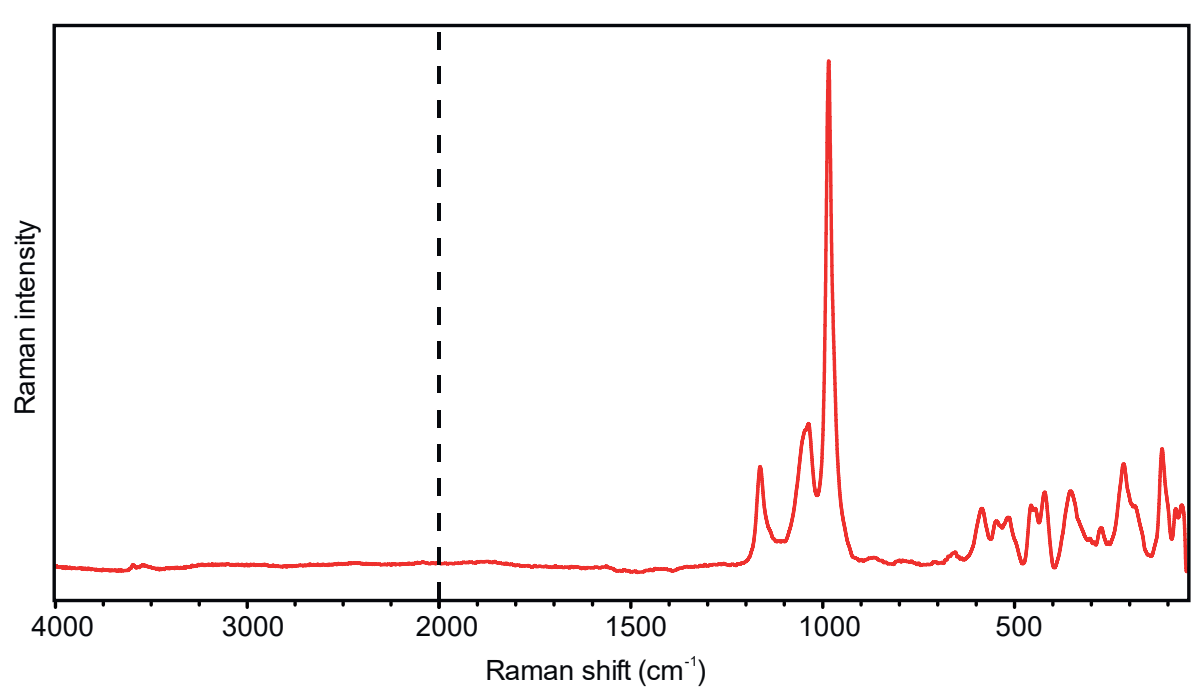

Tab. 5 Tentative assignment of Raman spectrum for ferraioloite from the Sítio de Castelo Mine

\begin{tabular}{|c|c|c|c|c|}
\hline $\begin{array}{l}\text { Wavenumber } \\
{\left[\mathrm{cm}^{-1}\right]}\end{array}$ & $\begin{array}{c}F W H M \\
{\left[\mathbf{c m}^{-1}\right]}\end{array}$ & $I_{\text {rel }} *$ & $I_{\text {rel }} * *$ & Tentative assignment \\
\hline 3594 & 16 & 1 & 1 & \multirow{2}{*}{$v \mathrm{OH}$ stretching vibrations of the hydroxyl units } \\
\hline 3538 & 60 & 1 & 4 & \\
\hline 3170 & 299 & 1 & 20 & \multirow{2}{*}{$\begin{array}{l}v \mathrm{OH} \text { stretching vibrations of hydrogen-bonded water } \\
\text { molecules in the interlayer space }\end{array}$} \\
\hline 2933 & 169 & 1 & 8 & \\
\hline 1163 & 21 & 27 & 31 & \multirow{5}{*}{$\begin{array}{l}v_{3} \mathrm{PO}_{4}^{3-} \text { triply degenerate antisymmetric stretching } \\
\text { vibrations }\end{array}$} \\
\hline 1140 & 28 & 7 & 10 & \\
\hline 1110 & 31 & 4 & 6 & \\
\hline 1052 & 45 & 28 & 68 & \\
\hline 1035 & 25 & 18 & 25 & \\
\hline 985 & 14 & 100 & 81 & \multirow{2}{*}{$v_{1} \mathrm{PO}_{4}^{3-}$ symmetric stretching vibrations } \\
\hline 978 & 34 & 53 & 100 & \\
\hline 657 & 20 & 2 & 2 & \multirow{7}{*}{$\begin{array}{l}v_{4}(\delta) \mathrm{PO}_{4}^{3-} \text { triply degenerate out-of-plane bending } \\
\text { vibrations }\end{array}$} \\
\hline 585 & 34 & 17 & 32 & \\
\hline 549 & 19 & 10 & 10 & \\
\hline 536 & 17 & 6 & 5 & \\
\hline 525 & 18 & 5 & 5 & \\
\hline 513 & 22 & 13 & 14 & \\
\hline 495 & 21 & 6 & 6 & \\
\hline 458 & 16 & 17 & 14 & \multirow{3}{*}{$\begin{array}{l}v_{2}(\delta) \mathrm{PO}_{4}^{3-} \text { doubly degenerate in-plane bending } \\
\text { vibrations }\end{array}$} \\
\hline 444 & 16 & 14 & 12 & \\
\hline 421 & 26 & 26 & 34 & \\
\hline 353 & 42 & 26 & 55 & \multirow{9}{*}{$\begin{array}{l}M-\mathrm{O} \text { stretching } \\
\mathrm{O}-M-\mathrm{O} \text { symmetric bending vibrations } \\
\text { lattice vibrations }\end{array}$} \\
\hline 320 & 31 & 10 & 16 & \\
\hline 301 & 18 & 7 & 7 & \\
\hline 292 & 5 & 2 & 1 & \\
\hline 274 & 31 & 17 & 27 & \\
\hline 253 & 10 & 2 & 2 & \\
\hline 231 & 40 & 18 & 37 & \\
\hline 215 & 23 & 25 & 29 & \\
\hline 200 & 23 & 12 & 15 & \\
\hline 183 & 27 & 21 & 29 & \multirow{8}{*}{ lattice vibrations } \\
\hline 167 & 22 & 11 & 12 & \\
\hline 147 & 25 & 12 & 15 & \\
\hline 133 & 14 & 9 & 7 & \\
\hline 116 & 19 & 44 & 43 & \\
\hline 100 & 19 & 23 & 23 & \\
\hline 80 & 17 & 26 & 24 & \\
\hline 61 & 21 & 34 & 38 & \\
\hline
\end{tabular}

* calculated from the band height

** calculated from the band area
Fig. 3 Full range Raman spectrum of ferraioloite from the Sítio do Castelo mine (split at $2000 \mathrm{~cm}^{-1}$ ).

In the phosphate $\mathrm{P}-\mathrm{O}$ stretching region (Frost et al. 2002), the strongest maximum composed of peaks at 985 and $978 \mathrm{~cm}^{-1}$ is interpreted as due to $v_{1} \mathrm{PO}_{4}$ symmetric stretching vibrations (Fig. 4b). Less distinct bands at 1052 and $1035 \mathrm{~cm}^{-1}$, as well as at 1163,1140 and $1110 \mathrm{~cm}^{-1}$, are attributed to $v_{3} \mathrm{PO}_{4}$ triply degenerate antisymmetric stretching vibrations. With $\mathrm{PO}_{4}$ vibrations, $\mathrm{ZnO}_{4}$ vibrations may overlap in this region (Kampf et al. 2021).

A series of peaks with gradually increasing intensity appears in the wavenumber region below $700 \mathrm{~cm}^{-1}$. This interval is shown in Fig. 4c and Fig. 4d. As regards the $\mathrm{PO}_{4}$ unit, two groups of overlapping bands in Fig. 4c can be assigned to $(i) v_{4}(\delta) \mathrm{PO}_{4}$ triply degenerate out-of-plane bending vibrations $\left(657-495 \mathrm{~cm}^{-1}\right)$ and (ii) $v_{2}(\delta) \mathrm{PO}_{4}$ doubly degenerate in-plane bending vibrations (458$\left.421 \mathrm{~cm}^{-1}\right)$. In the first-mentioned group, $\delta M-\mathrm{O}$ bending vibrations most likely occur and overlap the $\mathrm{PO}_{4}$ bands. The weak band observed at $657 \mathrm{~cm}^{-1}$ could be assigned to water libration modes, although the band position for the libration modes might be expected at higher wavenumbers (Frost et al. 2010). 

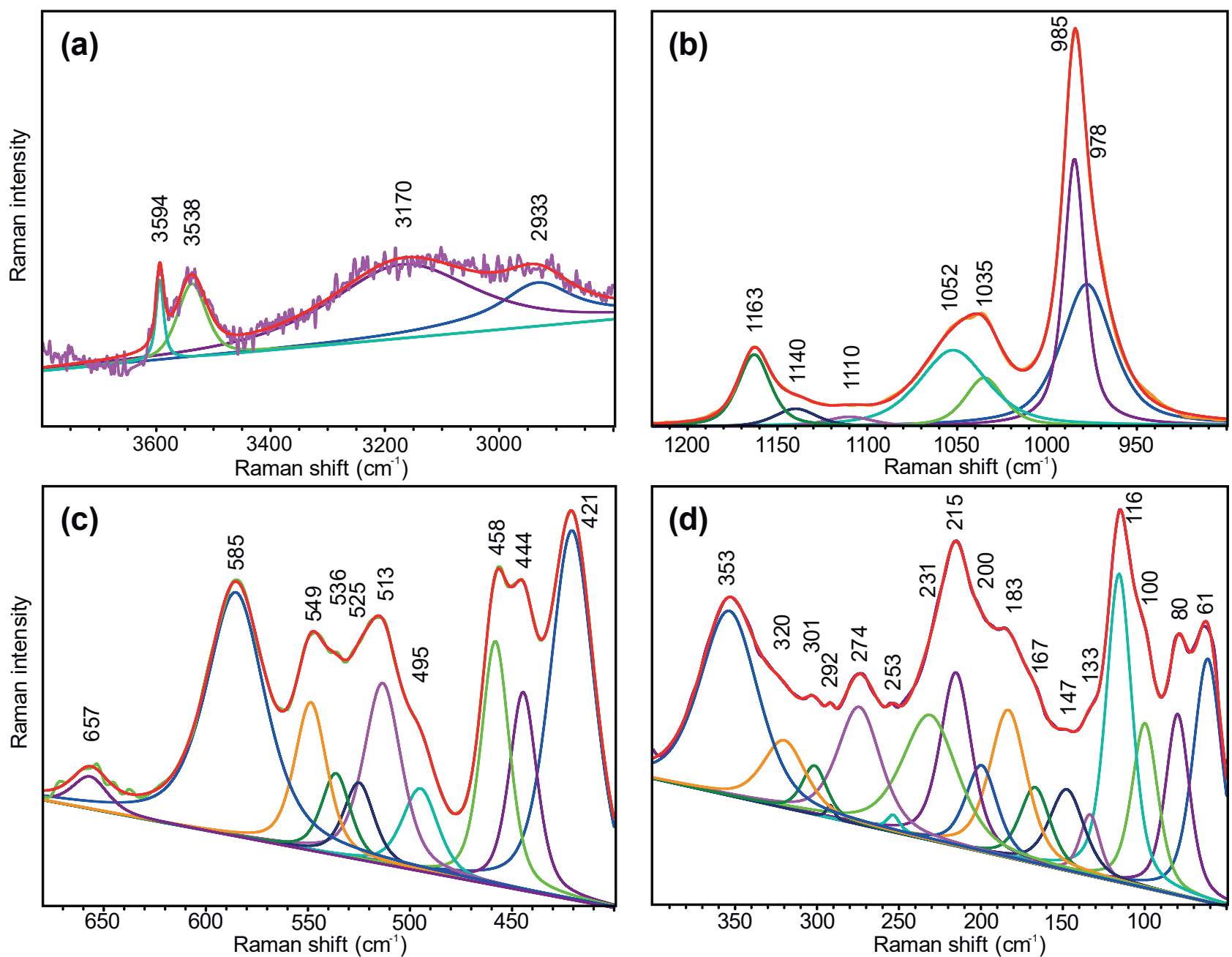

Fig. 4a-d Results of the band component analysis in the Raman spectrum.

In the low wavenumber region (Fig. 4d), bands attributed to vibrations of complex metal-centered polyhedra are shown. Bands of $M-\mathrm{O}$ stretching (most likely at $353-253 \mathrm{~cm}^{-1}$ ) overlap there those of $\mathrm{O}-M-\mathrm{O}$ symmetric bending (most likely at $231-200 \mathrm{~cm}^{-1}$ ) vibrations. The bands at lower wavelengths belong to external or lattice vibrations, but some can probably overlap to the range of higher wavenumbers. The band assignment in this spectral region is not entirely clear. For example, an intense band at $215 \mathrm{~cm}^{-1}$ observed in the bobierrite pattern is attributed to the $\mathrm{Mg}-\mathrm{O}$ stretching vibration (Frost et al. 2002), and conversely, bands below $249 \mathrm{~cm}^{-1}$ in pseudolaueite are considered to be lattice modes (Frost et al. 2015).

\section{Note on the origin}

Alves et al. (2012) pointed out the similarity of the phosphate occurrence in the Sítio do Castelo mine with those at the Krásno deposit in the Czech Republic (Sejkora et al.
2006). Characteristic primary phosphates at both localities are triplite and zwieselite, which were locally transformed to the isokite-fluorapatite mixture by metasomatic action of alkali-rich fluids in an early hydrothermal stage. The same solutions probably contained metals, including zinc, which resulted in the formation of sphalerite.

During late hydrothermal to supergene stages, extensive alteration led to leaching and redeposition of chemical components. In corrosion cavities in primary phosphates and on nearby and more distant fissures, a diverse suite of secondary minerals subsequently crystallized, containing additional elements introduced by circulating aqueous solutions. The studied ferraioloite is one of the youngest minerals in the locality. Considering that its occurrence is limited to an area only a few centimeters wide, the conditions for its formation had to be very specific. The mineral probably crystallized from alkaline solutions enriched in $\mathrm{Al}$ from aluminosilicates, and $\mathrm{Zn}, \mathrm{Ca}$ and $\mathrm{Mg}$ from sphalerite-rich fluorapatite-isok- 
ite assemblages in the Fe- and Mn-rich zwieselite-triplite environment.

\section{Conclusions}

Despite the expectation of Mills et al. (2016) to be found more often in other phosphate-bearing localities, the here described $\mathrm{Zn}$-phosphate from Sítio do Castelo mine seems to be the second known occurrence of ferraioloite. The studied sample shows specific differences compared to the type specimen from the Foote mine, USA, especially in the low content of $\mathrm{Mg}$ and a significant proportion of $\mathrm{Na}$ in the interlayer sites. Because it was impossible to obtain the data needed to determine the site's site occupancy in the mineral's crystal structure, we report the studied mineral phase as sodium-rich ferraioloite with large cations in the interlayer.

Acknowledgments. The authors wish to express their thanks to Jakub Plášil (Institute of Physics ASCR, Prague) for his kind support in this study, and Alexandre Lima (Departamento de Geociências, Ambiente e Ordenamento do Território, University of Porto) for information regarding the locality. Anthony R. Kampf, Ian E. Grey and Jan Cempírek are acknowledged for valuable comments and suggestions improving the manuscript. This work was supported financially by the Ministry of Culture of the Czech Republic (long-term project DKRVO 2019-2023/1.II.c National Museum, 00023272).

\section{References}

Alves P, Leal Gomes C, Lopes Nunes Je (2012) Produtos de evolução de triplite-zwieselite, fluorapatite e isokite da mina Sítio do Castelo (Folgosinho, Guarda). II Congresso Jovens Investigadores em Geociências, LEG 2012, 1-4

Alves P, Viñals J, Rewitzer C, Vila F, Meisser N (2016) Folgosinho: Secondary phosphates from the Sitio do Castelo mine - Gouveia, Guarda, Portugal. Mineral up 4: 6-27

BuRnham CW (1962) Lattice constant refinement. Carnegie Inst. Washington Year Book 61: 132-135

Chukanov NV, Vigasina MF (2020): Vibrational (infrared and Raman) spectra of minerals and related compounds. Springer Nature Switzerland, pp 1-1255

Frost RL, Martens W, Williams PA, Kloprogge JT (2002) Raman and infrared spectroscopic study of the vivianite-group phosphates vivianite, baricite and bobierrite. Mineral Mag 66: 1063-1073

Frost RL, Sejkora J, Keeffe EC, Plášil J, Čejka J, BAHFENNE S (2010) Raman spectroscopic study of the phosphate mineral churchite-(Y) $\mathrm{YPO}_{4} \cdot 2 \mathrm{H}_{2} \mathrm{O}$. J Raman Spectrosc 41: 202-206

Frost RL, Scholz R, Wang L (2015) A Raman and infrared spectroscopic study of the phosphate mineral pseudolaueite and in comparison with strunzite and ferrostrunzite. J Chem Crystallogr 45: 391-400

Garate-Olabe I, Roda-Robles E, Gil-Crespo PL, Pérez A, Vieira R, Lima A (2012) Estudio textural y mineralógico del dique de cuarzo con fosfatos de Folgosinho (Guarda, Portugal). Macla 16: 220-221

Grey IE, Kampf AR, Keck E, MacRae CM, Cashion JD, GozUKARA Y (2018) Crystal chemistry of schooneritegroup minerals. Eur J Mineral 30: 621-634

Kampf AR, Mills SJ, Simmons WB, Nizamoff JW, WhitMORE RW (2012) Falsterite, $\mathrm{Ca}_{2} \mathrm{MgMn}^{2+}{ }_{2}\left(\mathrm{Fe}^{2+}{ }_{0.5} \mathrm{Fe}^{3+}{ }_{0.5}\right)_{4}$ $\mathrm{Zn}_{4}\left(\mathrm{PO}_{4}\right)_{8}(\mathrm{OH})_{4}\left(\mathrm{H}_{2} \mathrm{O}\right)_{14}$, a new secondary phosphate mineral from the Palermo No. 1 pegmatite, North Groton, New Hampshire. Amer Miner 97: 496-502

Kampf AR, Grey IE, Alves P, Mills SJ, Nash BP, MacRae CM, KeCK E (2017) Zincostrunzite, $\mathrm{ZnFe}^{3+}{ }_{2}\left(\mathrm{PO}_{4}\right)_{2}(\mathrm{OH})_{2} \cdot 6.5 \mathrm{H}_{2} \mathrm{O}$, a new mineral from the Sítio do Castelo mine, Portugal, and the Hagendorf-Sud pegmatite, Germany. Eur J Mineral 29: 315-322

KampF AR, Celestian AJ, Nash BP (2021) Jasonsmithite, a new phosphate mineral with a complex microporous framework, from the Foote mine, North Carolina, U.S.A. Amer Miner 106: 174-179

Mills SJ, Grey IE, Kampf AR, Macrae CM, Smith JB, Davidson CJ, GLenn AM (2016) Ferraioloite, a new secondary phosphate mineral from the Foote mine, USA. Eur J Mineral 28: 655-661

NAKАмото K (2009) Infrared and Raman spectra of inorganic and coordination compounds. Part A: Theory and applications in inorganic chemistry. John Wiley \& Sons, Inc., Hoboken, New Jersey, pp 1-419

ONDRUŠ P (1993) ZDS - A computer program for analysis of X-ray powder diffraction patterns. Materials Science Forum 133-136, 297-300, EPDIC-2. Enschede

Pouchou J, Pichoir F (1985) „PAP“ ( $\phi \rho z)$ procedure for improved quantitative microanalysis. In: ARMSTRONG JT (ed): Microbeam Analysis: 104-106. San Francisco Press. San Francisco

SEJKora J, ŠKoda R, ONDRUŠ P, Beran P, SÜSSER C (2006) Mineralogy of phosphate accumulations in the Huber stock, Krásno ore district, Slavkovský les area, Czech Republic. J Czech Geol Soc 5: 103-147

Teixeira C, Brito De Carvalho lh, Paula Santos J, Martins Peres A, De Barros RF, Pilar L, Peinador Fernandes A, Tavares Rocha A (1967) Carta geológica de Portugal na Escala de 1/50000. Folha 17-D Gouveia. Serviços geológicos de Portugal, Lisboa

Yvon K, Jeitschko W, Parthé E (1977) Lazy Pulverix, a computer program for calculation X-ray and neutron diffraction powder patterns. J Appl Crystallogr 10: 73-74 